\title{
4-Hexylresorcinol induced angiogenesis potential in human endothelial cells
}

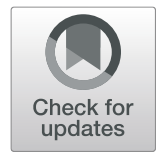

Min-Keun Kim', Seong-Gon Kim ${ }^{1 *}$ and Suk Keun Lee ${ }^{2^{*}}$

\begin{abstract}
Background: 4-Hexylresorcinol (4HR) is able to increase angiogenesis. However, its molecular mechanism in the human endothelial cells has not been clarified.

Methods: As endothelial cells are important in angiogenesis, we treated the human umbilical vein endothelial cells (HUVECs) with 4HR and investigated protein expressional changes by immunoprecipitation high-performance liquid chromatography (IP-HPLC) using 96 antisera.

Results: Here, we found that 4HR upregulated transforming growth factor- $\beta$ (TGF- $\beta$ )/SMAD/vascular endothelial growth factor (VEGF) signaling, RAF-B/ERK and p38 signaling, and M2 macrophage polarization pathways. 4HR also increased expression of caspases and subsequent cellular apoptosis. Mechanistically, 4HR increased TGF- $\beta 1$ production and subsequent activation of SMADsNEGFs, RAF-B/ERK and p38 signaling, and M2 macrophage polarization.

Conclusion: Collectively, 4HR activates TGF- $\beta$ /SMAD/NEGF signaling in endothelial cells and induced vascular regeneration and remodeling for wound healing.
\end{abstract}

Keywords: 4HR, HUVEC, IP-HPLC, TGF- $\beta 1$, Angiogenesis

\section{Background}

4-Hexylresorcinol (4HR) is a substituted phenol that is synthesized from resorcinol and caproic acid [1]. It is used as an antimicrobial in tooth pastes and skin lotions [2] and as a preservative for fresh fruits and vegetables [3]. It has bactericidal [4], anthelmintic [5], and potential antineoplastic activities [6], and thus, it is also used as an antiseptic in mouthwashes and skin wound cleansers [7]. 4HR may also inhibit oxidative DNA damage by enhancing the activities of antioxidant enzymes, including glutathione peroxidase and glutathione reductase, which facilitate the scavenging reactive oxygen species by glutathione [8], and thus, it is also used to prevent the enzymatic browning of shrimps and different fruits [9].

\footnotetext{
* Correspondence: kimsg@gwnu.ac.kr; sukkeunlee@hanmail.net

${ }^{1}$ Department of Oral and Maxillofacial Surgery, College of Dentistry,

Gangneung-Wonju National University, and Institute of Oral Science, 123

Chibyun-dong, Gangneung 210-702, Republic of Korea

2Department of Oral Pathology, College of Dentistry, Gangneung-Wonju

National University, and Institute of Oral Science, 123 Chibyun-dong,

Gangneung 210-702, Republic of Korea
}

\section{Springer Open}

(C) The Author(s). 2020 Open Access This article is licensed under a Creative Commons Attribution 4.0 International License, which permits use, sharing, adaptation, distribution and reproduction in any medium or format, as long as you give appropriate credit to the original author(s) and the source, provide a link to the Creative Commons licence, and indicate if changes were made. The images or other third party material in this article are included in the article's Creative Commons licence, unless indicated otherwise in a credit line to the material. If material is not included in the article's Creative Commons licence and your intended use is not permitted by statutory regulation or exceeds the permitted use, you will need to obtain permission directly from the copyright holder. To view a copy of this licence, visit http://creativecommons.org/licenses/by/4.0/.

A recent study demonstrated that $4 \mathrm{HR}$ increases the expression level of vascular endothelial growth factor (VEGF) in RAW264.7 cells and angiogenesis in the animal model [10]. 4HR increases M2 markers, and broadspectrum matrix metalloproteinase (MMP) inhibitor (PD166793) can reduce 4HR-induced VEGF expression. However, MMPs are also highly expressed in the inflammatory phase, and the expression of MMPs is mostly regulated by hypoxic stress [11]. Interestingly, the action of PD166793 is mediated by chelating zinc ion [12]. Accordingly, zinc-dependent protein like transforming growth factor- $\beta 1$ (TGF- $\beta 1$ ) may be regulated by $4 \mathrm{HR}$ and induce VEGF and angiogenesis.

Immunoprecipitation high-performance liquid chromatography (IP-HPLC) had been used previously by several authors to detect organic compounds quantitatively, including peptides, but the technique used was complicated and of limited applicability [13, 14]. Recently, a new IP-HPLC protocol was developed to determine protein expression levels in different biological fluids, such 
as blood serum, urine, saliva [15], inflammatory exudates [16-18], and different protein extracts from cells [1921], liver [22], and cancer tissues [21]. Recent IP-HPLC results demonstrate that $4 \mathrm{HR}$ administration increases the expression of TGF- $\beta 1$ in the osteoblast-like cells [23]. IP-HPLC is comparable to enzyme-linked immunosorbent assay (ELISA), but the former uses protein $\mathrm{A} / \mathrm{G}$ agarose beads in buffer solution and ultraviolet spectroscopy to determine protein concentrations, whereas the latter uses fluorescence-conjugated antibodies fixed in plastic wells and fluoroscopy. Furthermore, multiple trials have shown that IP-HPLC can be used to rapidly determine multiple protein levels accurately $( \pm 5 \%$ standard deviation) and reproducibly.

In this study, differentially expressed proteins by $4 \mathrm{HR}$ were screened by IP-HPLC in a human endothelial cell line (human umbilical vein endothelial cells [HUVECs]) using our antibody library. IP-HPLC results demonstrated that TGF- $\beta 1$ played a key role in $4 \mathrm{HR}$-induced activation of angiogenesis-associated signal pathway in HUVEC cells. To confirm this hypothesis, additional western blotting was done with TGF- $\beta 1$ and its signal blocker.

\section{Methods}

\section{HUVEC culture in the presence of $4 \mathrm{HR}$}

HUVECs (Lonza, Walkersville, MD, USA) were purchased and cultured in an endothelial basal medium supplemented with $1 \mu \mathrm{g} / \mathrm{mL}$ hydrocortisone, $12 \mu \mathrm{g} / \mathrm{mL}$ bovine brain extract, $50 \mu \mathrm{g} / \mathrm{mL}$ gentamicin, $50 \mathrm{ng} / \mathrm{mL}$ amphotericin-B, $10 \mathrm{ng} / \mathrm{mL}$ epidermal growth factor (EGF), VEGF, FGF-2, heparin, ascorbic acid, and 10\% fetal calf serum (EGM ${ }^{\mathrm{TM}^{-}}-2$, Clonetics ${ }^{\circ}$, Lonza, Walkersville, MD, USA) in $5 \% \mathrm{CO}_{2}$ at $37.5^{\circ} \mathrm{C}$. Cells were tested for mycoplasma on a regular basis to ensure that only mycoplasma-free cells were assayed.

About 70\% confluent HUVECs grown on Petri dish surfaces were treated with $10 \mu \mathrm{g} / \mathrm{mL} 4 \mathrm{HR}$ (with a single dose given safely given in dog; $100-300 \mathrm{mg} / \mathrm{kg}$, WHO food additives Series 35, 835) for 8, 16, or $24 \mathrm{~h}$; control cells were treated with $1 \mathrm{~mL}$ of normal saline. Cultured cells were harvested with protein lysis buffer (PROPREP $^{\mathrm{TM}}$, iNtRON Biotechnology INC, Korea) and immediately preserved at $-70^{\circ} \mathrm{C}$ until required.

\section{Immunoprecipitation high-performance liquid chromatography (IP-HPLC)}

Protein extracts $(100 \mu \mathrm{g})$ were subjected to immunoprecipitation using a protein A/G agarose column (Amicogen, Korea). Protein A/G agarose columns were separately pre-incubated with $1 \mu \mathrm{g}$ of 96 different antisera for growth factor-related proteins $(n=10)$, RAS signaling proteins $(n=22)$, NFkB signaling proteins $(n=$ $12[2])$, apoptosis-related proteins $(n=20)$, inflammatory proteins $(n=20)$, angiogenesis-related proteins $(n=14$
[3]), and control housekeeping proteins $(n=3)$ (numbers in brackets indicate the number of overlapping antibodies; Table 1).

Briefly, protein samples were mixed with $5 \mathrm{~mL}$ of binding buffer $(150 \mathrm{mM} \mathrm{NaCl}, 10 \mathrm{mM}$ Tris $\mathrm{pH} 7.4,1 \mathrm{mM}$ EDTA, $1 \mathrm{mM}$ EGTA, $0.2 \mathrm{mM}$ sodium vanadate, $0.2 \mathrm{mM}$ PMSF, and $0.5 \%$ NP-40) and incubated in protein $\mathrm{A} / \mathrm{G}$ agarose (Amicogen, Korea) columns on a rotating stirrer for $1 \mathrm{~h}$ at $4{ }^{\circ} \mathrm{C}$. After washing columns with PBS (phosphate-buffered saline solution), target proteins were eluted using $150 \mu \mathrm{L}$ of IgG elution buffer (Pierce, USA). Immunoprecipitated proteins were analyzed using an HPLC unit (1100 series, Agilent, USA) equipped with a reverse phase column and a micro-analytical detector system (SG Highteco, Korea). Elution was performed using $0.15 \mathrm{M} \mathrm{NaCl} / 20 \%$ acetonitrile solution at $0.4 \mathrm{~mL} /$ min for $30 \mathrm{~min}$, and proteins were detected using an ultraviolet spectrometer at $280 \mathrm{~nm}$. Control and experimental samples were run sequentially to allow comparisons. For IP-HPLC, whole protein peak areas (mAU*s) were calculated after subtracting negative control antibody peak areas, and square roots of protein peak areas were calculated to normalize concentrations. Protein percentages in total proteins in experimental and control groups were plotted. Results were analyzed using the chi-squared test [19-21].

The housekeeping proteins $\beta$-actin, $\alpha$-tubulin, and glyceraldehyde 3-phosphate dehydrogenase (GAPDH) were used as internal controls. Expressional changes of housekeeping proteins were adjusted to $< \pm 5 \%$ using a proportional basal line algorithm. Protein expressional changes of $\leq \pm 5 \%, \pm 5-10 \%, \pm 10-20 \%$, and $\geq \pm 20 \%$ change were defined as minimal, slight, meaningful, or marked, respectively.

\section{Statistical analysis}

Proportional data (\%) of the experimental and control groups were plotted into line graphs and star plots, and analyses were repeated two to six times until standard deviations were $\leq \pm 5 \%$. Line graphs revealed the similarities of the expression pattern between the relevant proteins, and star plots revealed the differences in the expression levels of the whole objective proteins. Results were analyzed using the chi-squared test. The expressions of control housekeeping proteins, that is, $\beta$-actin, $\alpha$-tubulin, and GAPDH, were nonresponsive $(\leq 5 \%)$ to 12,24 , or $48 \mathrm{~h}$ of $4 \mathrm{HR}$ treatment.

\section{Results}

Effects of $4 \mathrm{HR}$ on the expressions of growth factorrelated proteins in HUVECs

HUVECs treated with 4 HR showed marked increases in the expressions of TGF- $\beta 1(29.3 \%$ at $24 \mathrm{~h})$, TGF- $\beta 2$ (7.3\% at $8 \mathrm{~h}$ ), TGF- $\beta 3$ (22.3\% at $24 \mathrm{~h}), \mathrm{SMAD} 2 / 3(27.1 \%$ 
Table 1 Antibodies used in the study

\begin{tabular}{|c|c|c|}
\hline Protein & No. & Antibodies \\
\hline $\begin{array}{l}\text { Growth factor-related } \\
\text { protein }\end{array}$ & 10 & FGF-1*, FGF-2* , CTGF, TGF- $\beta 1^{\#}$, TGF- $\beta 2 *$, TGF- $\beta 3^{*}$, SMAD4*, SMAD2/3, p-SMAD4, PDGF-A* \\
\hline RAS signaling proteins & 22 & NRAS $\$$, KRAS $\$$, HRAS, PI3K, pAKT1/2/3, RAF-B* ${ }^{*}$ JNK-1*, p-JNK-1, ERK-1*, p-ERK-1 ${ }^{\$}$, Rab $1^{*}$, STAT3, p38*, p-p38* \\
\hline NFkB signaling proteins & $\begin{array}{l}12 \\
(2)\end{array}$ & NFkB*, IKK*, GADD45*, GADD153*, mTOR@ ${ }^{\circledR}$ NRF-2*, PGC-1a, SRC-1*, MDR, AMPK (p38*, p-p38*) \\
\hline Inflammatory proteins & 20 & $\begin{array}{l}\text { IL-10*, lysozyme*, granzyme, lactoferrin, M-CSF, Pdcd-1/1, HCAM, ICAM-1, COX2*, versican, TNFa }{ }^{@}, \text { IL-6* }{ }^{*}, \text { LTA4H }^{\&} \text {, } \\
\text { CXCR4, cathepsin C, cathepsin G*, MCP-1, CD68, CD99, TLR3 }\end{array}$ \\
\hline $\begin{array}{l}\text { Apoptosis-related } \\
\text { proteins }\end{array}$ & 20 & 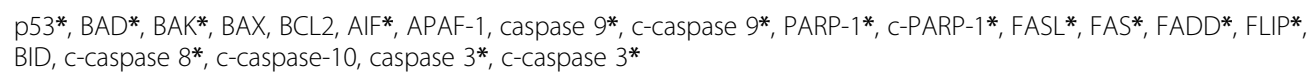 \\
\hline $\begin{array}{l}\text { Angiogenesis-related } \\
\text { proteins }\end{array}$ & $\begin{array}{l}14 \\
(3)\end{array}$ & $\begin{array}{l}\text { HIF-1a } a^{\&} \text {, angiogenin }{ }^{\$}, \text { VEGF-A*, VEGF-C* }{ }^{*} \text { VWF }^{\$}, \text { CMG }^{\$}, \text { FLT-4 } \\
\text { ICAM-1) LYVE-1*, MMP-2, MMP-10, PECAM-1 (FGF-2, PDGF-A, }\end{array}$ \\
\hline $\begin{array}{l}\text { ontrol housekeeping } \\
\text { roteins }\end{array}$ & 3 & a-Tubulin*, $\beta$-actin*, GAPDH* \\
\hline Total & & \\
\hline \multicolumn{3}{|c|}{ 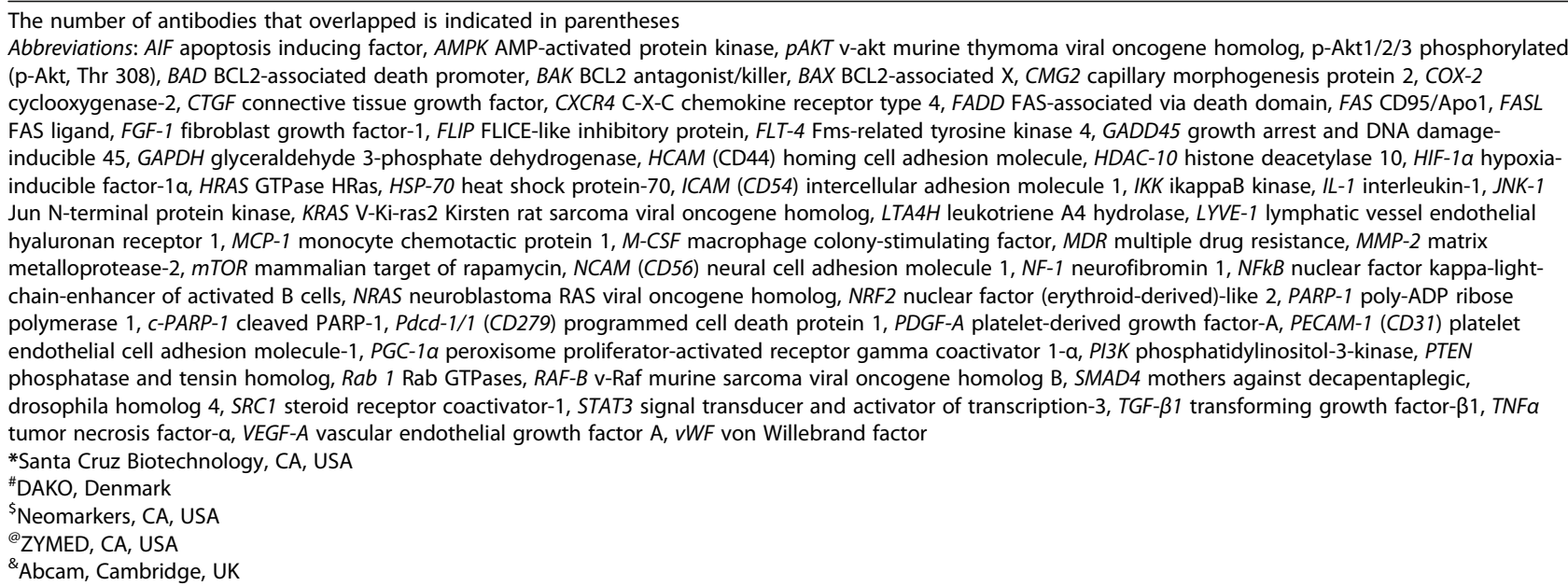 } \\
\hline
\end{tabular}

at $16 \mathrm{~h})$, SMAD4 $(13.4 \%$ at $8 \mathrm{~h})$, and p-SMAD4 $(13.3 \%$ at $16 \mathrm{~h})$ and a slight increase in the expression of connective tissue growth factor $(8.4 \%$ at $24 \mathrm{~h}$ ) as compared with nontreated control, but a decrease in the expression of fibroblast growth factor-1 (FGF-1; 16.4\% at 16 h), FGF-2 $(6.1 \%$ at $24 \mathrm{~h})$, and platelet-derived growth factor-A (PDGF-A; 5.1\% at 16 h; Fig. 1A1, A2).

These results indicate $4 \mathrm{HR}$ increased the expressions of growth factors associated with TGF- $\beta$ /SMAD pathways in HUVECs but slightly decreased the expressions of FGF-1, FGF-2, and PDGF-A. Therefore, we considered that 4HR provided dominant TGF- $\beta$-dependent angiogenesis in HUVECs despite downregulation of matrix angiogenetic factors (e.g., FGF-1, FGF-2, and PDGF-A).

\section{Effects of $4 \mathrm{HR}$ on the expressions of RAS signaling proteins in HUVECs}

The expressions of RAS signaling proteins were variable in HUVECs treated with 4 HR for $24 \mathrm{~h}$. K-RAS expression gradually decreased by $16.2 \%$ at $24 \mathrm{~h}, \mathrm{H}$-RAS expression decreased by $9 \%$ at $8 \mathrm{~h}$ but increased by $3.7 \%$ at $24 \mathrm{~h}$ versus nontreated control, while N-RAS increased by $2 \%$ at $16 \mathrm{~h}$ and by $1.6 \%$ at $24 \mathrm{~h}$. Downstream signal proteins SOS1/2 and STAT3 tended to be decreased by $11.3 \%$ and $5 \%$ at $16 \mathrm{~h}$, respectively.

4HR upregulated RAF-B, a growth signal transduction protein kinase, by $27.8 \%$ at $2 \mathrm{~h}$ in HUVECs and subsequently upregulated mitogen-activated protein kinase 3, also known as extracellular signal-regulated kinase (ERK-1) and p-ERK-1 (Thr 202/Tyr 204) by $9.1 \%$ and $15.8 \%$ at 24 h, respectively. 4HR also upregulated p38 mitogen-activated protein kinase (p38, 15.8\% at $16 \mathrm{~h}$ ) and phosphorylated p38 (p-p38, 12.2\% at $8 \mathrm{~h}$ ). The critical mediator of growth factor-induced signals pAKT1/2/3 (Thr 308) was consistently downregulated by $21.3 \%$ at $24 \mathrm{~h}$ and by $15.1 \%$ at $8 \mathrm{~h}$, and phosphorylated c-Jun N-terminal kinase-1 (p-JNK-1, 89; Thr 183/Tyr 185), which is responsible for stress stimuli, such as cytokinesultraviolet irradiation, heat shock, and osmotic shock, was also downregulated by $24.5 \%$ at $16 \mathrm{~h}$ and by $21.5 \%$ at $24 \mathrm{~h}$, although the expression of non-phosphorylated JNK-1 was slightly increased by $3.7 \%$ at $24 \mathrm{~h}$ (Fig. 1)B1, B2). On the other hand, 4HR-treated HUVECs showed decreases in the 


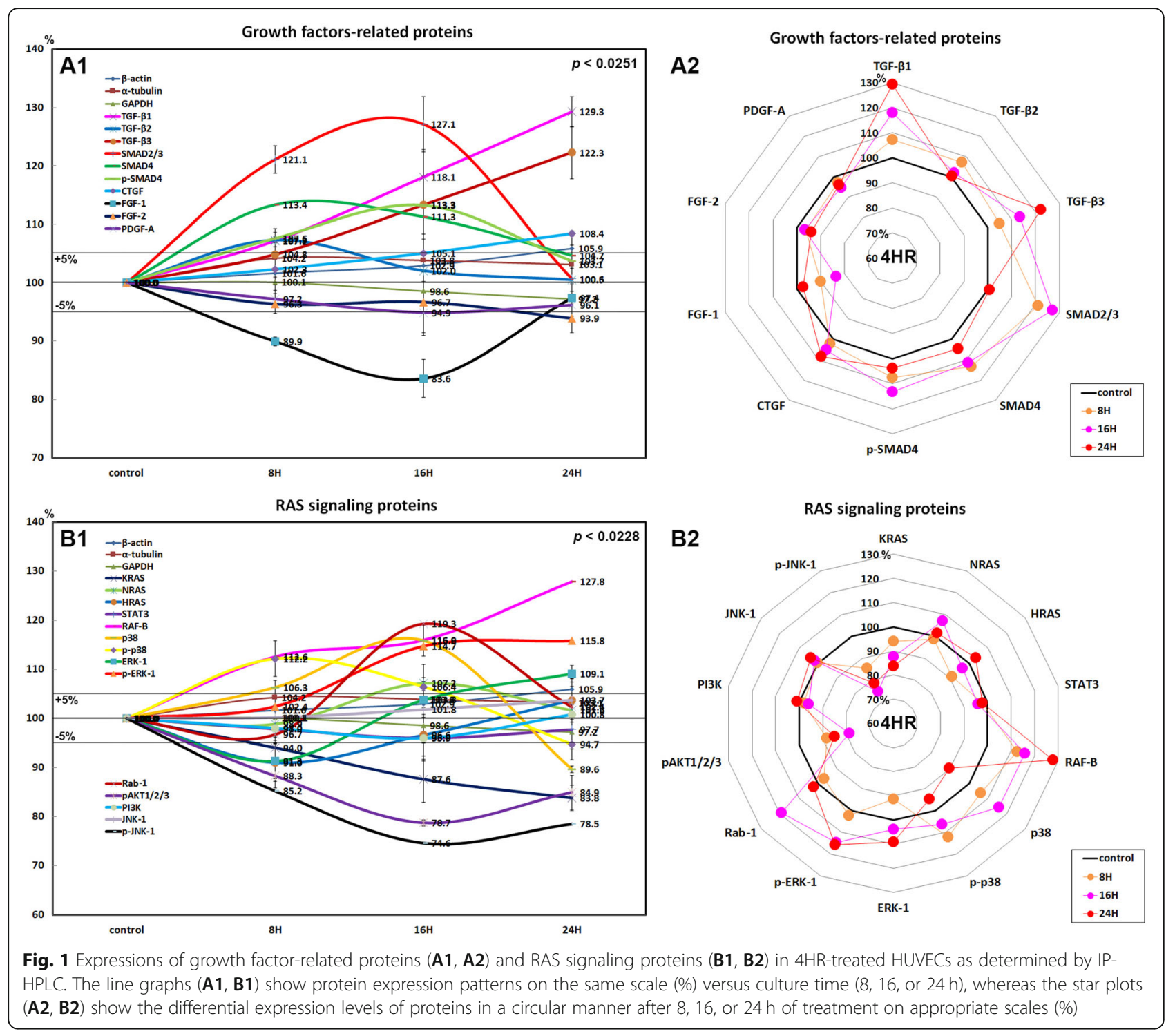

expressions of protein kinase $\mathrm{C}$ (PKC; $18.6 \%$ at $8 \mathrm{~h}$ ) and pPKC $(13.4 \%$ at $8 \mathrm{~h})$ but minimal expression changes of phosphatidylinositol 3-kinase (PI3K), A-kinase anchoring proteins (AKAP), and phosphatase and tensin homolog (PTEN) by $\pm 5 \%$. These results indicate that 4 HR significantly upregulated the downstream effectors of RAS signaling, RAF-B/ERK-1 and p38 in HUVECs, while it attenuated other RAS signaling pathways (e.g., AKT and JNK signaling) and minimally affected the expressions of PI3K, AKAP, and PTEN.

\section{Effects of $4 \mathrm{HR}$ on the expressions of NFkB signaling proteins in HUVECs}

$4 \mathrm{HR}$ had different effects on the expressions of nuclear factor kappa-light-chain-enhancer of activated B cells (NFkB) signaling proteins in HUVECs. The expression of NFkB was slightly decreased by $6.2 \%$ at $24 \mathrm{~h}$ versus nontreated controls, while the expressions of ikappaB kinase (IKK), p38, and p-p38, negative regulators of NFkB function, were increased by $9.3 \%$ at $16 \mathrm{~h}, 15.8 \%$ at $16 \mathrm{~h}$, and $12.2 \%$ at $8 \mathrm{~h}$, respectively.

$4 \mathrm{HR}$ diffusely decreased the expressions of downstream NFkB signaling proteins such as growth arrest and DNA damage 45 (GADD45; 7.8\% at 24 h), GADD153 (19.5\% at $16 \mathrm{~h}$ ), mammalian target of rapamycin (mTOR; $27.8 \%$ at $8 \mathrm{~h}$ ), nuclear factor (erythroid-derived 2)-like 2 (NRF2; $8.9 \%$ at $24 \mathrm{~h}$ ), multiple drug resistance (MDR; $12.5 \%$ at 16 h), and $5^{\prime}$ AMP-activated protein kinase (AMPK; $15.9 \%$ at $8 \mathrm{~h}$ ), but it increased the expressions of peroxisome proliferator-activated receptor gamma coactivator $1-\alpha$ (PGC-1 $\alpha ; 27.6 \%$ at $24 \mathrm{~h}$ ) and steroid receptor coactivator1 (SRC1; $18.9 \%$ at 24 h; Fig. 2A1, A2).

These results indicate that $4 \mathrm{HR}$ significantly suppressed NFkB signaling in HUVECs through upregulation of 


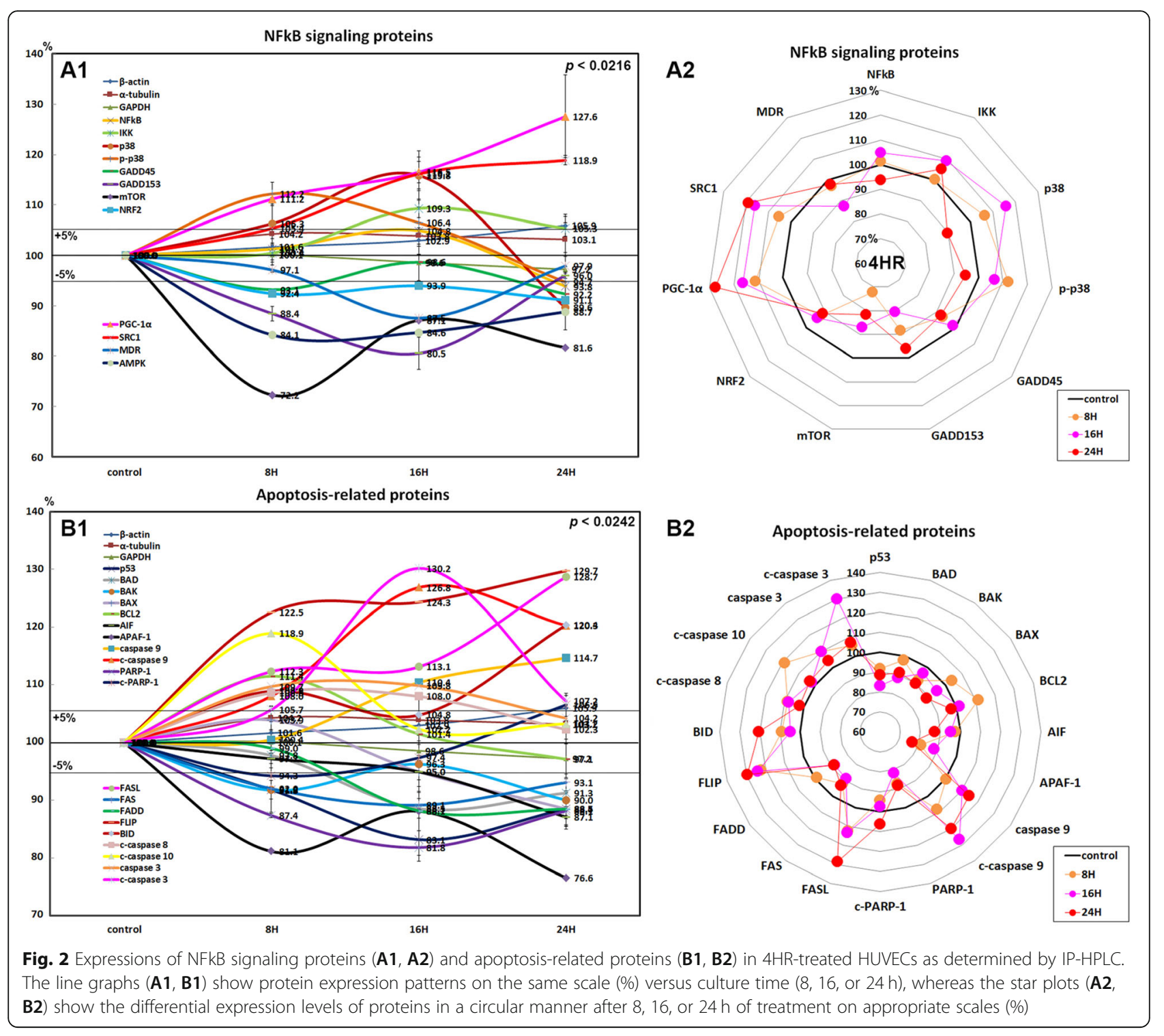

negative regulators and downregulation of multiple downstream effector proteins.

\section{Effects of $4 \mathrm{HR}$ on the expressions of apoptosis-related proteins in HUVECs}

$4 \mathrm{HR}$ affected the expressions of p53-mediated apoptosisrelated proteins, particularly p53 protein, which was decreased by $16.9 \%$ after treatment for $16 \mathrm{~h}$ as compared with nontreated controls, and decreased the expressions of proapoptotic proteins, BCL2-associated death promoter (BAD; $11.5 \%$ at $16 \mathrm{~h}$ ), BCL2 homologous antagonist/killer (BAK; $10 \%$ at $24 \mathrm{~h})$, apoptosis regulator BAX $(11.5 \%$ at $24 \mathrm{~h})$, and apoptotic protease activating factor 1 (APAF-1; $23.4 \%$ at 24 h) but increased the expression of B cell lymphoma 2 (BCL2; $11.4 \%$ at $8 \mathrm{~h}$ ) and apoptosis inducing factor (AIF; $13.5 \%$ at 8 h). On the other hand, the expressions of apoptosis executor proteins such as caspase 9 and c-caspase 9 were increased by $13.9 \%$ at $24 \mathrm{~h}$ and by $19 \%$ at $16 \mathrm{~h}$, respectively (Fig. 2B1, B2). These results indicate that $4 \mathrm{HR}$ activated caspase 9 and c-caspase 9 via AIF signaling in the lack of upregulation of pro-apoptotic factors, including BAD, BAK, BAX, and APAF-1.

HUVECs treated with 4HR showed decreases in the expressions of FAS-mediated apoptosis signaling proteins as compared with nontreated controls, although they showed an increase in the expression of FAS ligand (FASL; 28.7\% at $24 \mathrm{~h})$. After treatment with $4 \mathrm{HR}$ for $24 \mathrm{~h}$, the expression of death receptors on cell surfaces, that is, FAS, was decreased by $10.9 \%$ at $16 \mathrm{~h}$ and that of FAS-associated protein with death domain (FADD) was also decreased by $11.9 \%$ at $16 \mathrm{~h}$, but FLICE-like inhibitory protein (FLIP) expression was increased by $29.7 \%$ at $24 \mathrm{~h}$, whereas HUVECs treated with $4 \mathrm{HR}$ showed increases in the expressions of apoptosis executor proteins, c-caspase 8 (by $8.6 \%$ at 8 h), c-caspase 10 (18.9\% 
at $8 \mathrm{~h}$ ), caspase 3 (by $9.8 \%$ at $16 \mathrm{~h}$ ), and c-caspase 3 (by $30.2 \%$ at $16 \mathrm{~h}$ ), and $\mathrm{BH} 3$ interacting-domain death agonist (BID; $20.4 \%$ at 24 h; Fig. 2)B1, B2). These results indicate $4 \mathrm{HR}$ activated caspase 8 , caspase 10 , and caspase 3 independently from FAS-mediated signaling proteins.

On the other hand, HUVECs treated with 4HR showed decreases in the expressions of poly-[ADP-ribose] polymerase 1 (PARP-1; 18.2\% at $16 \mathrm{~h}$ ) and cleaved PARP-1 (c-PARP1; $5.7 \%$ at 8 h; Fig. 2)B1, B2). These results indicate $4 \mathrm{HR}$ rarely produced single-strand DNA breaks, which require repair by PARP-1.

\section{Effects of 4HR on the expressions of inflammatory proteins in HUVECs}

$4 \mathrm{HR}$ influenced the expressions of inflammatory proteins positively or negatively in HUVECs depending on the types of M1/M2 macrophage polarization. The proteins upregulated by $4 \mathrm{HR}$ usually belong to M2 macrophage polarization proteins, which were interleukin-10 (IL-10; $15.1 \%$ at $16 \mathrm{~h})$, lysozyme $(25.5 \%$ at $24 \mathrm{~h})$, granzyme B $(33.9 \%$ at $24 \mathrm{~h})$, lactoferrin $(37.9 \%$ at $24 \mathrm{~h})$, macrophage colony-stimulating factor (M-CSF; $17.6 \%$ at $8 \mathrm{~h}$ ), programmed cell death protein 1 (Pdcd-1/1, CD279; $19.8 \%$ at $24 \mathrm{~h}$ ), homing cell adhesion molecule (HCAM, CD44; $25.5 \%$ at $16 \mathrm{~h}$ ), intercellular adhesion molecule 1 (ICAM-1, CD54; $14.9 \%$ at $8 \mathrm{~h}$ ), cyclooxygenase 2 (COX-2; $35.3 \%$ at $24 \mathrm{~h})$, and versican $(25.3 \%$ at $24 \mathrm{~h})$ as compared with nontreated controls. The downregulated proteins by $4 \mathrm{HR}$ usually belong to M1 macrophage polarization proteins, which were tumor necrosis factor $\alpha$ (TNFo; $28.9 \%$ at $24 \mathrm{~h}), \mathrm{IL}-6$ (16.6\% at $24 \mathrm{~h}$ ), leukotriene A4 hydrolase (LTA4H; $19.7 \%$ at $24 \mathrm{~h}$ ), C-X-C chemokine receptor type 4 (CXCR4, CD184; $8.1 \%$ at $8 \mathrm{~h}$ ), cathepsin C $(22.5 \%$ at $24 \mathrm{~h})$, cathepsin $\mathrm{G}(18.1 \%$ at $8 \mathrm{~h})$, monocyte chemotactic protein-1 (MCP-1; 21.1\% at 24h), CD68 (20.7\% at $16 \mathrm{~h})$, CD99 (25.7\% at $16 \mathrm{~h})$, and toll-like receptor 3 (TLR3; $16.2 \%$ at $24 \mathrm{~h}$; Fig. 3A1, A2).

These results indicate that HUVECs treated with $4 \mathrm{HR}$ for $24 \mathrm{~h}$ showed upregulation of M2 macrophage polarization proteins (IL-10, lysozyme, granzyme B, lactoferrin, M-CSF, Pdcd-1/1, HCAM, ICAM-1, COX-2, and versican) but downregulation of M1 macrophage polarization proteins (TNF $\alpha$, IL-6, LTA4H, CXCR4, cathepsin C, cathepsin G, MCP-1, CD68, CD99, and TLR3).

\section{Effects of $4 \mathrm{HR}$ on the expressions of angiogenesis-related proteins in HUVECs}

HUVECs treated with $4 \mathrm{HR}$ showed increases in the expressions of angiogenesis-related proteins for $24 \mathrm{~h}$, as follows: angiogenin $(27.6 \%$ at $24 \mathrm{~h})$, VEGF-A $(24.1 \%$ at $24 \mathrm{~h})$, VEGF-C (19.1\% at $24 \mathrm{~h})$, von Willebrand factor (vWF; $17.4 \%$ at $16 \mathrm{~h}$ ), capillary morphogenesis protein 2 (CMG2; $19.7 \%$ at $24 \mathrm{~h}$ ), Fms-related tyrosine kinase 4
(FLT-4; $27.7 \%$ at $16 \mathrm{~h}$ ), lymphatic vessel endothelial hyaluronan receptor 1 (LYVE-1; $28.1 \%$ at $24 \mathrm{~h}$ ), ICAM-1 $(17.7 \%$ at $16 \mathrm{~h})$, and platelet endothelial cell adhesion molecule-1 (PECAM-1, CD31; 19.8\% at $8 \mathrm{~h}$ ), but they showed decreases in the expressions of hypoxiainducible factor- $1 \alpha$ (HIF- $1 \alpha ; 19.7 \%$ at $24 \mathrm{~h}$ ), fibroblast growth factor-2 (FGF-2; $6.1 \%$ at $24 \mathrm{~h}$ ), PDGF-A (5.1\% at $16 \mathrm{~h}), \mathrm{MMP}-2(11.2 \%$ at $8 \mathrm{~h})$, and MMP-10 $(7.2 \%$ at $8 \mathrm{~h}$; Fig. 3B1, B2).

These results indicate that HUVECs treated with $4 \mathrm{HR}$ for $24 \mathrm{~h}$ showed dramatic upregulation of cellular angiogenetic proteins including angiogenin, VEGF-A, VEGFC, vWF, CMG2, FLT4, LYVE-1, ICAM-1, and PECAM-1 independently from angiogenesis transcription factor $(\mathrm{HIF}-1 \alpha)$ and matrix angiogenetic factors (FGF-2, PDGF-A, MMP-2, and MMP-10).

\section{Global protein expressions in 4HR-induced HUVECs}

Global protein expression changes of representative proteins $(n=51)$ selected from 6 different protein signaling pathways above are illustrated as a star plot in Fig. 4. The growth factor-related proteins (TGF- $\beta 1$, TGF- $\beta 2$, TGF- 33 , SMAD2/3, SMAD4, and p-SMAD4), RAS signaling proteins (NRAS, RAF-B, p38, p-p38, ERK-1, and pERK-1), cellular apoptosis-related proteins (caspase 9, c-caspase 9, caspase 8, c-caspase 10, caspase 3, and ccaspase 3), M2 macrophage polarization proteins (IL-10, lysozyme, granzyme B, lactoferrin, M-CSF, Pdcd-1/1, COX-2, and versican), and angiogenesis-related proteins (angiogenin, VEGF-A, VEGF-C, vWF, CMG2, FLT4, LYVE-1, ICAM-1, and PECAM-1) were upregulated in HUVECs treated with $4 \mathrm{HR}$ for $16 \mathrm{~h}$, while the NFkB signaling proteins (NFkB, GADD45, GADD135, mTOR, NRF2, and $\mathrm{MDR}$ ) and $\mathrm{M} 1$ macrophage polarization proteins (TNF $\alpha$, IL-6, LTA4H, CXCR4, cathepsin C, cathepsin G, MCP-1, CD68, CD99, and TLR3) were downregulated.

These results indicate that HUVECs treated with 4HR for $16 \mathrm{~h}$ may have strong angiogenetic potential with concurrent elevation of TGF- $\beta /$ SMAD signaling, RAF-B/ERK and p38 signaling, and $M 2$ macrophage polarization and that 4HR-induced activation of caspases and subsequent cellular apoptosis in the reduction of NFkB signaling compensate by stimulating the expressions of TGF- $\beta$ s in HUVECs.

\section{Discussion}

4HR is a phenolic compound with a hexane chain. Because it is strongly hydrophobic, 4HR can adhere to some proteins and change their molecular conformation into inactive status [24]. In a previous study on the 4HR adhering assay [19], TNF $\alpha$, lysozyme, PDGF-A, FLT4, pAKT1/2/3, PKC, and GADD45 were significantly adherent to 4HR, but other proteins examined in this study, including growth factor-related proteins (TGF- $\beta 1$, TGF- $\beta 2$, TGF- $\beta 3$, SMADs), RAS signaling proteins 


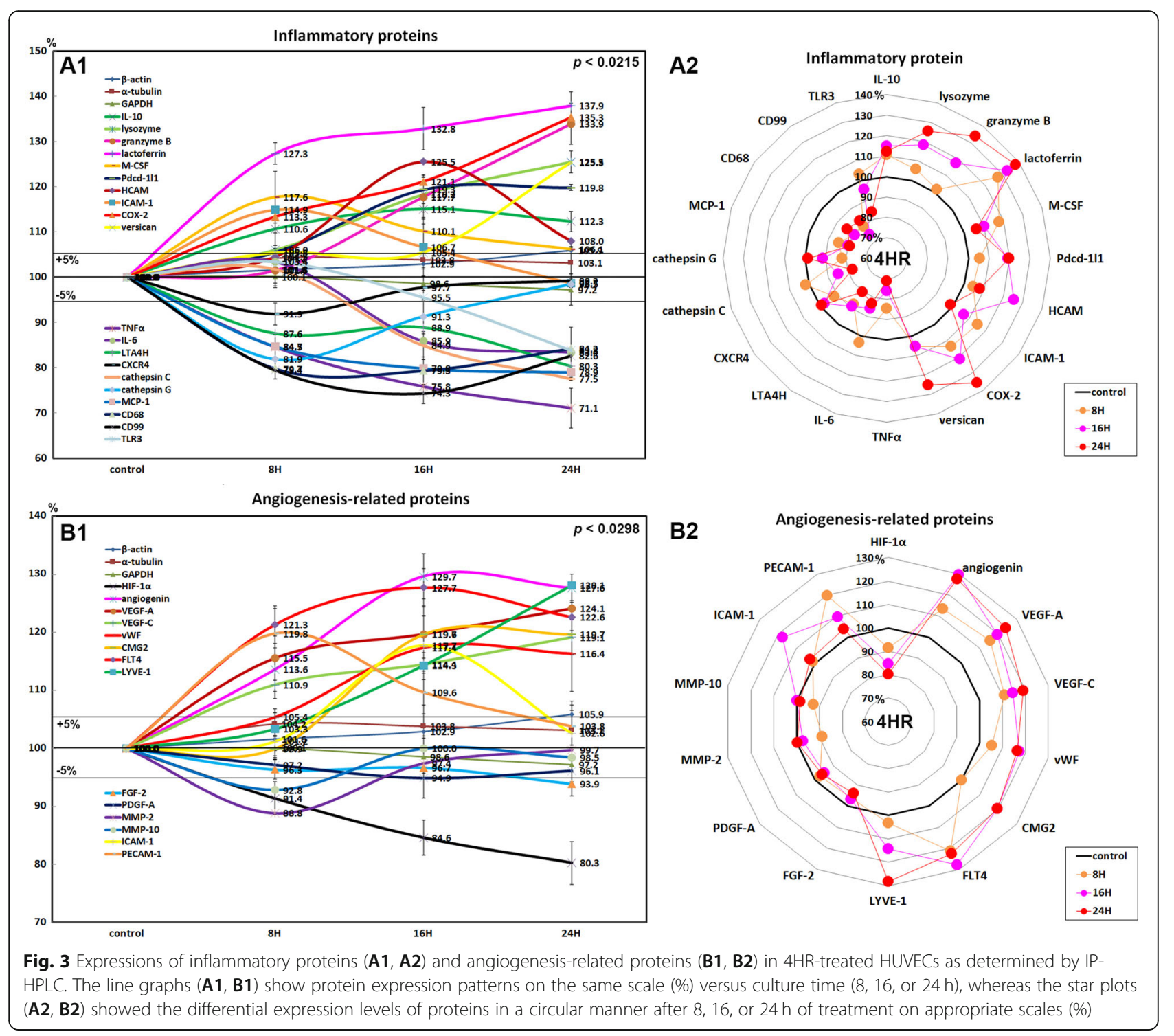

(RAF-B/ERK and p38 pathways), NFkB signaling proteins, apoptosis-related proteins (caspase-3, caspase-8, caspase-9, caspase-10), inflammatory proteins (IL-10, MCSF, COX-2, LTA4H, CXCR4, MCP-1, etc.), and angiogenesis-related proteins (angiogenin, VEGF-A, VEGF-C, CMG2, LYVE-1, etc.), were almost nonadherent or minimal adherent $(<5 \%)$ to 4 HR-coated beads. These results indicate the expression changes of different proteins observed in this study were due to the active interaction between $4 \mathrm{HR}$ and target proteins rather than the direct denaturation of target proteins by $4 \mathrm{HR}$ adherence. Therefore, these results suggested that the different molecular signaling by 4-HR in HUVECs be reproducible and devoid of further oxidative stresses or endoplasmic reticulum stresses.

4HR-treated HUVECs showed alternative cellular apoptosis caused by activation of different caspases (cleaved caspase-3, caspase-8, caspase-9, and caspase-10) despite the reduction of p53- and FAS-mediated pro-apoptotic signaling. Although the present study did not elucidate whether $4 \mathrm{HR}$ could damage the mitochondrial membrane, it was thought that the relatively innocuous $4 \mathrm{HR}$, which did not elicit any oxidative stress in cells [19], produced abortive mitochondrial biogenesis by upregulation of PGC- $1 \alpha$ and AIF but downregulation of AMPK (energy consumption) simultaneously in HUVECs resulting in alternative apoptosis by activation of caspases released from 4HR-involved mitochondria.

This 4HR-induced cellular apoptosis would be slowly progressed with no activation of NFkB signaling and compensate by stimulating TGF- $\beta$ production in HUVECs. Actually, in the present study, 4HR-treated HUVECs showed dominant expressions of TGF- $\beta 1$, TGF- $\beta 2$, and TGF- $\beta 3$ despite consistent downregulation 


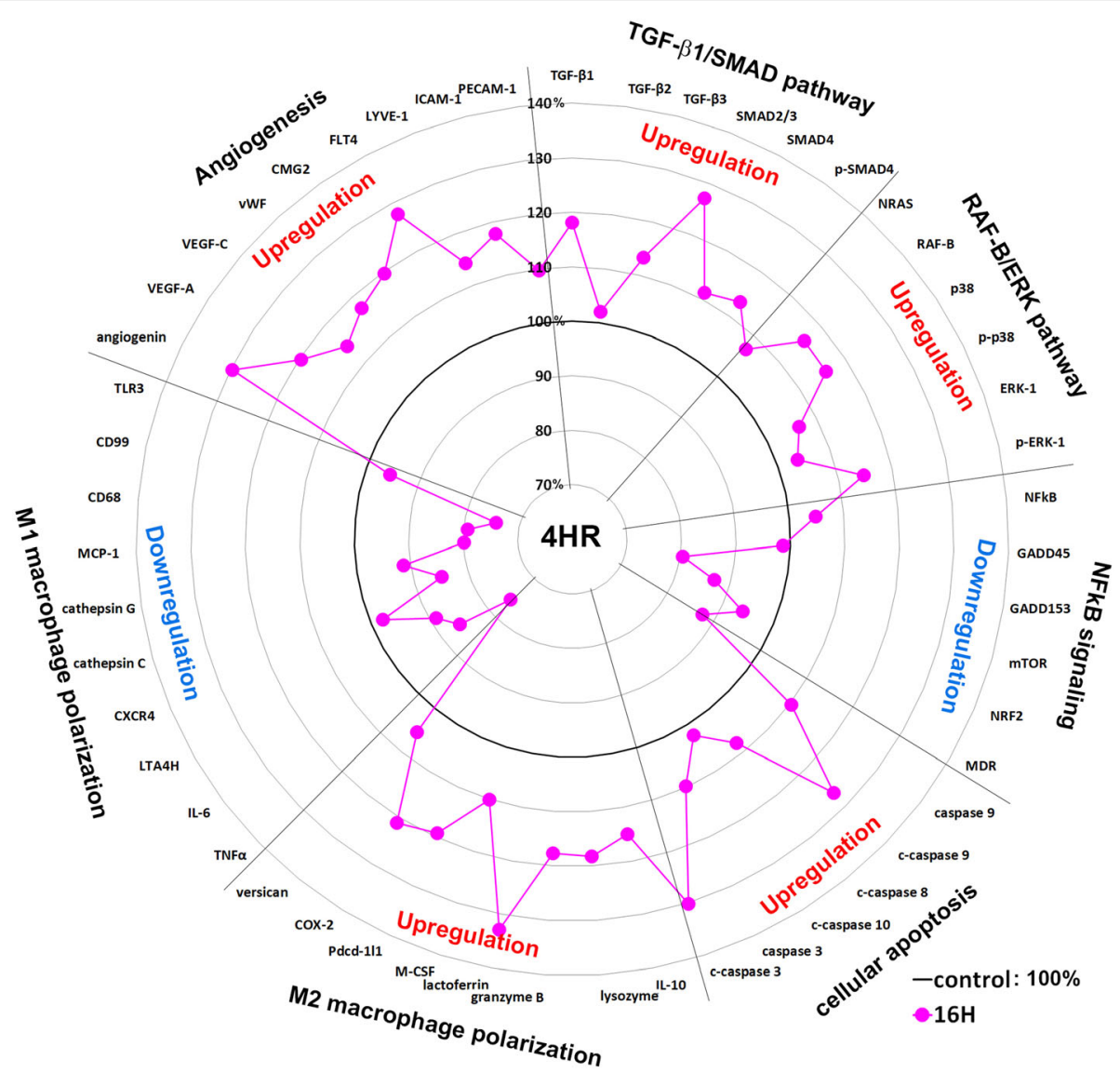

Fig. 4 Star plot of global protein expression in HUVECs treated with 4HR for $16 \mathrm{~h}$. The expression levels (\%) of representative proteins $(n=51)$ selected from 6 major molecular signaling pathways are plotted in a circular manner. The expressions of growth factor-related proteins (TGF- $\beta$ / SMAD signaling), RAS signaling proteins (RAF-B/ERK and p38 signaling), cellular apoptosis-related proteins (apoptosis executor proteins; caspase-3, caspase-8, caspase-9, caspase-10), M2 macrophage polarization proteins, and angiogenesis-related proteins were upregulated, while the expressions of NFkB signaling proteins and M1 macrophage polarization proteins were downregulated

of FGF-1, FGF-2, FGF-7, growth hormone, growth hormone releasing hormone, PDGF-A, and c-erbB-2 (HER2; some data not shown). The dominant expressions of TGF- $\beta 1$, TGF- $\beta 2$, and TGF- $\beta 3$ were very characteristic in 4 HR-treated HUVECs. However, when TGF- $\beta$ ligands bind to TGF- $\beta$ receptors (heteromeric complex of type I and type II TGF- $\beta$ receptors), it is expected that the SMAD2/3/4 pathway is activated and undergoes target gene transcription such as VEGFs and BMPs and that RAF-B/ERK and p38 signaling are activated and crosstalk with TGF- $\beta /$ SMAD signaling. These TGF- $\beta$ signaling cascades were found as marked upregulation and activation of RAF-B, SMADs, ERK-1, p38, and VEGFs in the present 4 HR-treated HUVECs. In addition, the administration of A83-01, a Smad pathway blocker, showed marked reduction of VEGF expression, which was expected to be increased by $4 \mathrm{HR}$ treatment.

In the previous study, we found that $4 \mathrm{HR}$ induced potent de novo angiogenesis in both in vitro and in vivo experiments [10]. 4HR treatment increased VEGF expression in RAW264.7 cells, and it is HIF independent. The present study explored the molecular mechanism of 4HR-induced angiogenesis in HUVECs and observed that 4HR-treated HUVECs showed dominant expressions of TGF- $\beta$ s concurrently with upregulation of SMADs and VEGFs. In addition, it has been confirmed that TGF- $\beta 1$ stimulates SMAD pathway and increases VEGF-A expression in in vitro culture of HUVECs. Therefore, it is suggested that 4HR-induced angiogenesis in HUVECs is characteristic with serial activation of cellular angiogenetic factors in the TGF- $\beta$ /SMAD/VEGF pathways independent from the ordinary angiogenesis transcription factor (HIF-1 $\alpha)$ and matrix angiogenetic factors (FGF-2, PDGF-A, MMP-2, and MMP-10).

On the other hand, 4HR-treated HUVECs expressed a higher level of M2 macrophage polarization proteins (cytokines) than nontreated controls and a lower level of M1 macrophage polarization proteins. The upregulation of M2 macrophage polarization cytokines might autonomously stimulate HUVECs to undergo cytological 
changes appropriate for angiogenesis, subsequently followed by HUVEC differentiation via TGF- $3 /$ SMAD/ VEGF signaling in vitro. Our previous study reported that 4HR induced a strong wound-healing effect with de novo angiogenesis associated with M2 macrophage infiltration in in vivo animal experiments [25, 26]. In this study, however, the HUVEC culture contained no macrophages, so there was no cellular interaction between HUVECs and macrophages, resulting in a diminished angiogenetic effect of M2 macrophage polarization cytokines on HUVECs. Among 4HR-induced angiogenic effects, M2 macrophage polarization proteins will be more greatly amplified in in vivo animal experiments, where macrophages can be infiltrated, than in in vitro cell culture. In addition, 4HR can increase the expression level of M2 markers in RAW264.7 cells directly [10].

The global protein expression changes are illustrated in Fig. 4 using 51 representative proteins selected from 6 major molecular signaling pathways. It was found that 4HR-treated HUVECs showed concurrent upregulation of TGF- $\beta /$ SMAD/VEGF signaling, RAF-B/ERK and p38 signaling, and M2 macrophage polarization and that 4HR-induced activation of caspases and subsequent cellular apoptosis were closely relevant to the overexpression of TGF- $\beta s$ in HUVECs. If the protein expression patterns obtained from precision IP-HPLC analysis were similar to each other at their level (\%) and time after $4 \mathrm{HR}$ treatment, the concurrent protein expression changes in the same functional groups may have implications for the signal transduction or cross-talk to achieve the final goals of objective proteins. Therefore, two major angiogenetic pathways induced by $4 \mathrm{HR}$ were identified from the above global protein expression data analyzed by IP-HPLC: the caspase activation/TGF- $\beta$ / SMAD/VEGF pathway and reduced NFkB signaling/upregulation of M2 macrophage polarization proteins/ endothelial cell differentiation in HUVECs (Fig. 5).

Angiogenesis is a vital step for uneventful wound healing. The materials inducing M2 macrophage polarization are required for angiogenesis and wound remodeling [27]. $4 \mathrm{HR}$ is an agent for M2 macrophage polarization [10]. In this study, 4HR increased the expression level of

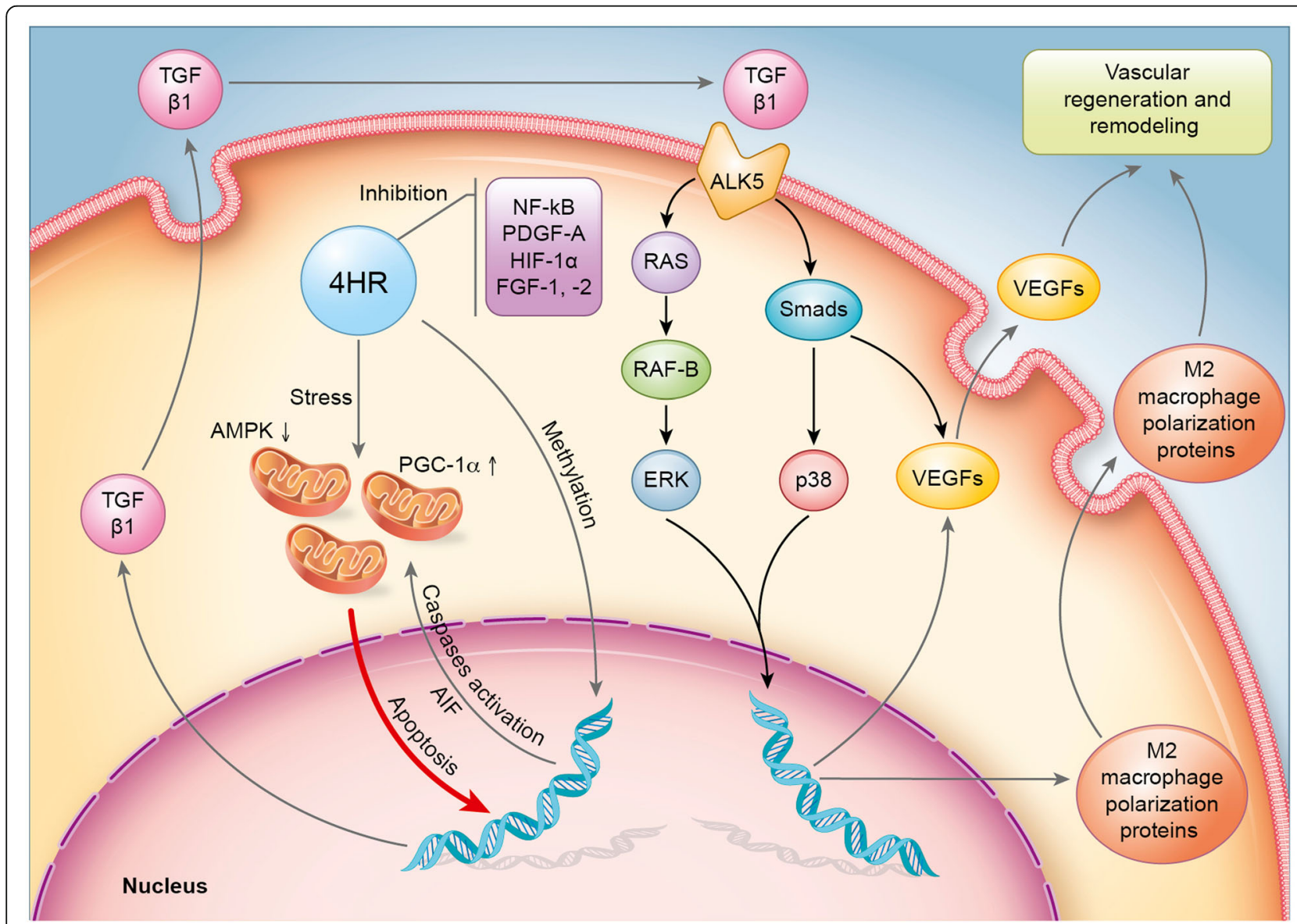

Fig. 5 Schematic drawings for the proposed mechanism. Apoptotic stress on the mitochondria is induced by application of $4 \mathrm{HR}$. This stress induces TGF- $\beta 1$ expression, and secreted TGF- $\beta 1$ protein will bind to ALK5. Then, the downstream signal is generated by the RAS/Smads pathway. This signal will increase the expression of VEGFs 
proteins that are responsible for endothelial cell differentiation (Fig. 5). In future perspective, 4HR incorporating materials may be developed for the maxillofacial regeneration. Actually, 4HR incorporated xenograft has been shown reduced foreign body reaction [28] and accelerated degradation [29]. Bone grafts with 4HR suppress NFkB signaling and increase bone regeneration [30].

\section{Conclusion}

Collectively, 4HR-induced angiogenic factors (VEGFs) were controlled by TGF- $\beta 1$ overexpression and subsequent activation of SMADs/VEGFs, RAF-B/ERK and p38 signaling, and M2 macrophage polarization. Therefore, it is assumed that $4 \mathrm{HR}$ activates TGF- $\beta /$ SMAD/ VEGF signaling and induced vascular regeneration and remodeling for wound healing. In particular, the overexpression of TGF- $\beta$ s in 4 HR-treated HUVECs might be ascribed to the increase of apoptosis via FAS-mediated signaling, and the dominant TGF- $\beta 1$ expression might induce the protein expressions of M2 macrophage polarization proteins, which subsequently stimulate wound-healing procedures.

\section{Abbreviations}

4HR: 4-Hexylresorcinol; VEGF: Vascular endothelial growth factor; MMP: Matrix metalloproteinase; TGF- $\beta 1$ : Transforming growth factor- $\beta 1$; IP-

HPLC: Immunoprecipitation high-performance liquid chromatography; ELISA: Enzyme-linked immunosorbent assay; HUVECs: Human umbilical vein endothelial cells

\section{Acknowledgements}

This study was carried out with the support of "Cooperative Research Program for Agriculture Science and Technology Development (Project no. PJ01313902)" Rural Development Administration, Republic of Korea.

\section{Third party rights}

The images/drawings/photographs were taken or created by an author of the paper.

\section{Authors' contributions}

The study design was done by KSG and LSK. IP-HPLC was done by KMK and LSK. The manuscript was written by KSG and LSK. The authors read and approved the final manuscript.

\section{Funding}

This study was carried out with the support of "Cooperative Research Program for Agriculture Science and Technology Development (Project no. PJ01313902)" Rural Development Administration, Republic of Korea.

\section{Availability of data and materials}

Not applicable.

\section{Ethics approval and consent to participate}

Not applicable.

\section{Consent for publication}

Not applicable.

\section{Competing interests}

The authors declare that the authors have no competing interests as defined by Nature Research or other interests that might be perceived to influence the results and/or discussion reported in this paper.
Received: 27 March 2020 Accepted: 11 May 2020

Published online: 29 June 2020

\section{References}

1. McConnell VF (1953) Hlasiwetz and Barth - pioneers in the structural aspects of plant products. J Chem Educ 30:380-385

2. Wilson CO, Gisvold O, Doerge RF (1966) Textbook of organic medicinal and pharmaceutical chemistry, 5th edn. Lippincott, Philadelphia, PA, USA, pp $237-262$

3. He J, Zhu Q, Dong X, Pan H, Chen J, Zheng ZP (2017) Oxyresveratrol and ascorbic acid O/W microemulsion: preparation, characterization, antiisomerization and potential application as antibrowning agent on fresh-cut lotus root slices. Food Chem 214:269-276

4. Darlow HM, Powell EO, Bale WR, Morris EJ (1958) Observations on the bactericidal action of hexyl resorcinol aerosols. J Hyg 56:108-124

5. Brkic D (1956) Intestinal parasites: helminths; with special reference to newer antihelminthics. Srp Arh Celok Lek 84:1401-1416

6. Ujiie T (1968) Experimental anticancer studies. XXXIV. Some compounds relating to 4-n-hexyl-6-(2-hydroxyphenyliminomethyl) resorcinol and their anticancer activity. Chem Pharm Bull 16:165-171

7. Chevalier M, Sakarovitch C, Precheur I, Lamure J, Pouyssegur-Rougier V (2015) Antiseptic mouthwashes could worsen xerostomia in patients taking polypharmacy. Acta Odontol Scand 73:267-273

8. Yen GC, Duh PD, Lin CW (2003) Effects of resveratrol and 4-hexylresorcinol on hydrogen peroxide-induced oxidative DNA damage in human lymphocytes. Free Radic Res 37:509-514

9. Guandalini E, loppolo A, Mantovani A, Stacchini P, Giovannini C (1998) 4-Hexylresorcinol as inhibitor of shrimp melanosis: efficacy and residues studies; evaluation of possible toxic effect in a human intestinal in vitro model (Caco-2); preliminary safety assessment. Food Addit Contam 15: $171-180$

10. Jo YY, Kim DW, Choi JY, Kim SG (2019) 4-Hexylresorcinol and silk sericin increase the expression of vascular endothelial growth factor via different pathways. Sci Rep 9:3448

11. Liu Y, Zhang H, Yan L, Du W, Zhang M, Chen H, Zhang L, Li G, Li J, Dong Y, Zhu D (2018) MMP-2 and MMP-9 contribute to the angiogenic effect produced by hypoxia/15-HETE in pulmonary endothelial cells. J Mol Cell Cardiol 121:36-50

12. Gresele P, Falcinelli E, Momi S (2008) Potentiation and priming of platelet activation: a potential target for antiplatelet therapy. Trends Pharmacol Sci 29:352-360

13. Clarke NJ, Tomlinson AJ, Ohyagi Y, Younkin S, Naylor S (1998) Detection and quantitation of cellularly derived amyloid beta peptides by immunoprecipitation-HPLC-MS. FEBS letters 430:419-423

14. Luo L, Shen L, Sun F, Ma Z (2013) Immunoprecipitation coupled with HPLCMS/MS to discover the aromatase ligands from Glycyrrhiza uralensis. Food Chem 138:315-320

15. Kim YS, Lee SK (2015) IP-HPLC analysis of human salivary protein complexes. Kor J Oral Maxillofac Pathol 39:615-622

16. Kim SM, Eo MY, Cho YJ, Kim YS, Lee SK (2018) Immunoprecipitation high performance liquid chromatographic analysis of healing process in chronic suppurative osteomyelitis of the jaw. J Craniomaxillofac Surg 46:119-127

17. Kim SM, Eo MY, Cho YJ, Kim YS, Lee SK (2017) Wound healing protein profiles in the postoperative exudate of bisphosphonate-related osteonecrosis of mandible. Eur Arch Otorhinolaryngol 274:3485-3495

18. Kim SM, Eo MY, Cho YJ, Kim YS, Lee SK (2017) Differential protein expression in the secretory fluids of maxillary sinusitis and maxillary retention cyst. Eur Arch Otorhinolaryngol 274:215-222

19. Kim MK, Yoon CS, Kim SG, Park YW, Lee SK (2019) Effects of 4-hexylresorcinol on protein expressions in RAW 264.7 cells as determined by immunoprecipitation high performance liquid chromatography. Sci Rep 9:3379

20. Yoon CS, Kim MK, Kim YS, Lee SK (2018) In vitro protein expression changes in RAW 264.7 cells and HUVECs treated with dialyzed coffee extract by immunoprecipitation high performance liquid chromatography. Sci Rep 8 : 13841

21. Kim SM, Jeong D, Kim MK, Lee SS, Lee SK (2017) Two different protein expression profiles of oral squamous cell carcinoma analyzed by immunoprecipitation high-performance liquid chromatography. World J Surg Oncol 15:151 
22. Yoon CS, Kim MK, Kim YS, Lee SK (2018) In vivo protein expression changes in mouse livers treated with dialyzed coffee extract as determined by IP-HPLC. Maxillofac Plast Reconstr Surg 40:44

23. Choi KH, Kim DW, Lee SK, Kim SG, Kim TW (2020) The administration of 4-hexylresorcinol accelerates orthodontic tooth movement and increases the expression level of bone turnover markers in ovariectomized rats. Int J Mol Sci 21(4):1526

24. Feng S, Song XH, Zeng CM (2012) Inhibition of amyloid fibrillation of lysozyme by phenolic compounds involves quinoprotein formation. FEBS letters 586:3951-3955

25. Ahn J, Kim SG, Kim MK, Kim DW, Lee JH, Seok H, Choi JY (2016) Topical delivery of 4-hexylresorcinol promotes wound healing via tumor necrosis factor-alpha suppression. Burns 42:1534-1541

26. Kang YJ, Noh JE, Lee MJ, Chae WS, Lee SY, Kim SG (2016) The effect of 4-hexylresorcinol on xenograft degradation in a rat calvarial defect model. Maxillofac Plastic Reconstr Surg 38:29

27. Kim SG (2020) Immunomodulation for maxillofacial reconstructive surgery. Maxillofac Plast Reconstr Surg 42:5

28. Kweon H, Kim SG, Choi JY (2014) Inhibition of foreign body giant cell formation by 4-hexylresorcinol through suppression of diacylglycerol kinase delta gene expression. Biomaterials 35(30):8576-8584

29. Jo YY, Kweon H, Kim DW, Kim MK, Kim SG, Kim JY, Chae WS, Hong SP, Park YH, Lee SY, Choi JY (2017) Accelerated biodegradation of silk sutures through matrix metalloproteinase activation by incorporating 4-hexylresorcinol. Sci Rep 7:42441

30. Song JY, Kim SG, Park NR, Choi JY (2018) Porcine bone incorporated with 4-hexylresorcinol increases new bone formation by suppression of the nuclear factor kappa B signaling pathway. J Craniofac Surg 29(7):1983-1990

\section{Publisher's Note}

Springer Nature remains neutral with regard to jurisdictional claims in published maps and institutional affiliations.

\section{Submit your manuscript to a SpringerOpen ${ }^{\circ}$ journal and benefit from:}

- Convenient online submission

- Rigorous peer review

- Open access: articles freely available online

High visibility within the field

- Retaining the copyright to your article

Submit your next manuscript at $\boldsymbol{\nabla}$ springeropen.com 